\title{
Groundwater flow and volcanic unrest
}

\author{
Alia Jasim, Brioch Hemmings, Klaus Mayer \\ and Bettina Scheu
}

\begin{abstract}
Hydrology around active volcanoes is strongly controlled by the interaction between groundwater, and the fluids, dissolved elements and heat associated with magmatic intrusion. The chemical and mechanical processes associated with magmatic unrest can result in observable changes in the hydrothermal system. Consequently, observations of chemical and physical hydrothermal variations may provide insights into the state of volcanic activity. Additionally, the interaction between hydrological and volcanic systems leads to the presence of high-temperature, pressurised, and often acidic fluids, which add to, and intensify, the volcanic hazard. In the following chapter we present the major components of, and controls on, magmatic hydrothermal systems focusing on the mutual perturbation between the groundwater flow system and the volcanic system. We
\end{abstract}

\section{A. Jasim $(\square)$ \\ University of Bristol, Earth Science School, Wills Memorial Building, Queen's Road, Clifton BS8 1RJ, UK}

K. Mayer · B. Scheu

Department of Earth and Environmental Sciences, Ludwig-Maximilians-Universität München (LMU), Theresienstrasse 41/III, 80333 Munich, Germany

B. Hemmings

GNS Science, 1 Fairway Drive, Lower Hutt, New Zealand explore how these conditions can be modified by volcanic unrest and we identify feedbacks between dynamic hydrothermal behaviour and on-going unrest. The interaction between these systems, and therefore the associated monitoring signals, are the result of complex groundwater-volcano coupling within multi-phase flow system in evolving lithologies. Nonetheless, detailed monitoring of hydrothermal and hydrological behaviour can provide insights into unrest and the evolution of hazards at restless volcanoes.

\section{Keywords}

Hydrothermal system - Groundwater

Fluid flow $\cdot$ Permeability $\cdot$ Unrest-monitoring

\section{Resumen}

Brevemente resumimos nuestra comprensión de los sistemas magmáticos hidrotermales y discutimos las mayores incógnitas y sus implicaciones en el vigilancia volcánica. También proveemos directrices adicionales para la recolección de datos a usarse en la calibración de la variabilidad del sistema de aguas subterráneas, alrededor de volcanes activos, como un paso crucial para desacoplar las señales magmáticas de las puramente hidrotermales. 
La interacción entre los sistemas hidrológico y volcánico es un elemento importante durante reactivación volcánica. Los cambios en el comportamiento hidrológico de un volcán activo, como la elevación del nivel del agua subterránea, la descarga de manantiales, los cambios de temperatura y de la química, pueden ser indicadores preliminares de evolución de la actividad volcánica. Las interacciones hidrológicas pueden también alterar y aumentar el peligro volcánico existente. Las interacciones físicas y químicas entre la roca encajante y los diferentes tipos de fluido pueden modificar los caminos de desgasificación, generando distribuciones de presión dinámicas dentro del edificio volcánico. Aún los procesos lentos, como el desarrollo creciente de zonas de alteración permanentes, pueden manifestarse como un peligro dinámico asociado con una reactivación continua o futura, ya que las rocas altamente cristalinas son hidrotérmicamente alteradas produciendo arcillas débiles secundarias. Discutimos los principales parámetros que controlan las reacciones y sus efectos en la distribución de la alteración en ambientes volcánicos.

Debido a la introducción del calor de la fuente en el sistema del agua saturada, se presentan peligros adicionales. Esto frecuentemente conlleva a explosiones freáticas y freato-magmáticas. La presencia de paquetes de gases bajo la superficie además incrementa este peligro. El balance entre el ingreso de agua freca fría, la desgasificación y la disipación de calor, está críticamente relacionado con la abilidad del sistema para transmitir fluidos, el mismo que evoluciona en función tanto de los procesos químicos (ej., las reacciones de dilución/precipitación mineral) como físicos (ej., fracturamiento y compactación de la roca), produciendo así propiedades hidrológicas de la roca fuertemente dependientes de la escala (ej., porosidad, permeabilidad y conductividad térmica).

En resumen, las señales físicas y químicas, o la perturbación hidrológica asociada con la reactivación magmática, son complejas y dependientes del sitio. Las contribuciones de los diferentes componentes del fluido, y sus interacciones con caminos de flujo existentes, pueden determinar cómo un sistema evoluciona en períodos de calma. Esta evolución controla la posible respuesta a la perturbación termodinámica y química asociada con la iniciación de la reactivación volcánica. Dadas las intrincadas retroalimentaciones entre el magma, la hidrología, y los cambios repentinos de los sistemas involucrados, únicamente mediciones de alta frecuencia (de horas a semanas) de la temperatura, $\mathrm{pH}$, conductividad eléctrica del agua, profundidad del nivel del agua subterránea, del contenido de REE (Elementos de Tierras Raras), RFEs (Elementos de Formación de Rocas) y gas disuelto, conjuntamente con mediciones geofísicas, pueden aclarar la evolución del sistema magmático, la apertura/cierre de fracturas y la dinámica estacional del agua subterránea.

\section{Introduction}

Much of the research relating to the interaction between hydrological and volcanic systems has focused on the role of hydrothermal systems in the development of economic mineral deposits. hydrothermal systems have formed vast ore-deposits around the world, most of them clearly result from the interaction between magmatic and meteoric fluids (Hedenquist and Lowenstern 1994).

The interaction between hydrological and volcanic systems is an important element in volcanic unrest. Changes in hydrological behaviour, such as water table elevation, spring discharge, temperature and chemistry, at an active volcano can provide early indications of changes in volcanic activity. Hydrological interactions can also alter and augment the existing volcanic hazard. Chemical and physical interactions between host rocks and different fluid types can modify fluid degassing pathways, generating dynamic pressure distributions within a volcanic edifice. Additional hazards are also presented by the introduction of a heat source into a water saturated system, this frequently results in dangerous phreatic and phreatomagmatic explosions. Understanding the controls on hydrological and hydrothermal behaviour in volcanic settings is essential for understanding the array of hazards 
presented by volcanic unrest. Continued development of this understanding is also providing new volcano monitoring opportunities. Despite the clear relevance and importance of hydrological and volcanic interactions in relation to volcanic unrest, the dynamics of this interaction remain poorly constrained.

\section{Hydrothermal System}

Although insulated or distal, cool groundwater aquifers can respond to volcanic perturbation, the clearest manifestation of volcanic and hydrological interactions is a hydrothermal system. Fumaroles, often visible on active volcanoes, represent the surface expression of this hydrothermal system.

A magmatic hydrothermal system is composed of three main elements: a host rock (or reservoir), which contains a circulating fluid, set in motion by an igneous heat source (Fig. 1). While the difference in relief between stratovolcanoes and calderas can lead to contrasting hydrological systems, the lower limit of any hydrological system is commonly defined as the brittle-ductile transition zone. Within this zone, fluid pressures transition from hydrostatic to lithostatic as rock permeability becomes severely reduced (Fournier 1999). When this region is subjected to high strain rates, fracturing may occur, leading to episodic influxes of mass and heat to the hydrothermal system (Bodnar et al. 2007). While agreement exists on the definition of lower limit of a volcanic hydrological system, the same is not true for the upper limit.

We consider the water table as the upper limit of the hydrological system. However, the earth's surface could equally be considered part of the system. This adds the further complexity of flow within the unsaturated (vadose) zone (Hemmings et al. 2015a). Furthermore, the upper limit of the hydrological system closely depends on the precipitation regime. Precipitation is a function of geography, including both latitude and elevation. Together with surface processes it determines the recharge dynamics of the aquifer and the depth and fluctuation of the water table. A number of studies suggest a correlation between the fluctuation of the water table and elevated seismicity. Both the reduction in effective stress due to a seasonal increase in hydrostatic pore pressure, and the snow unloading, lead to a seasonal peak of seismicity (Saar and Manga 2003; Christiansen et al. 2005). Furthermore, Mason et al. (2004) identify seasonal peaks in the eruption rate of volcanoes, which may be due to the load/unload seasonal stress cycle imposed by the hydrological cycle.

The definition of water table implies a water saturated medium below it. However, crater lakes (Fournier et al. 2009) and caldera settings (Bruno et al. 2007; Jasim et al. 2015) often have portion of the water table sustained by a two phases system (liquid and gas). Similarly, the condensation of magmatic gases (primarily vapour) often feeds the groundwater reservoir (Chiodini et al. 2001). While the location of the water table is important, the conventional definition does not really apply in volcanic settings, especially in high-relief stratovolcanoes, in which it is often unclear to what extent the edifice is water saturated. Specifically, the local water table may differ from the regional water table, with highly dynamic elevation changes controlled by both meteoric and volcanic processes.

Many studies suggest the presence of high elevation springs, however it is not clear whether they are fed by the regional water table or by perched saturated layers high up on the cone (Cabrera and Custodio 2004; Custodio 2007; Cruz and Oliveira Silva 2001; Hemmings et al. 2015a; Ingebritsen and Scholl 1993; Join et al. 2005; Peterson 1972). Access to wells on the flank of volcanoes and geophysical imaging methods can help resolve the hydrogeology behind such springs (Finn et al. 1987, 2001; Aizawa et al. 2008). However, in either scenario, the development of saturated flow units at high elevation has a particular relevance to forecasting volcanic hazards such as lahar, landslides and flank collapses, which can be sudden, unpredicted and deadly. Such mass wasting events all involve the displacement of material from the 


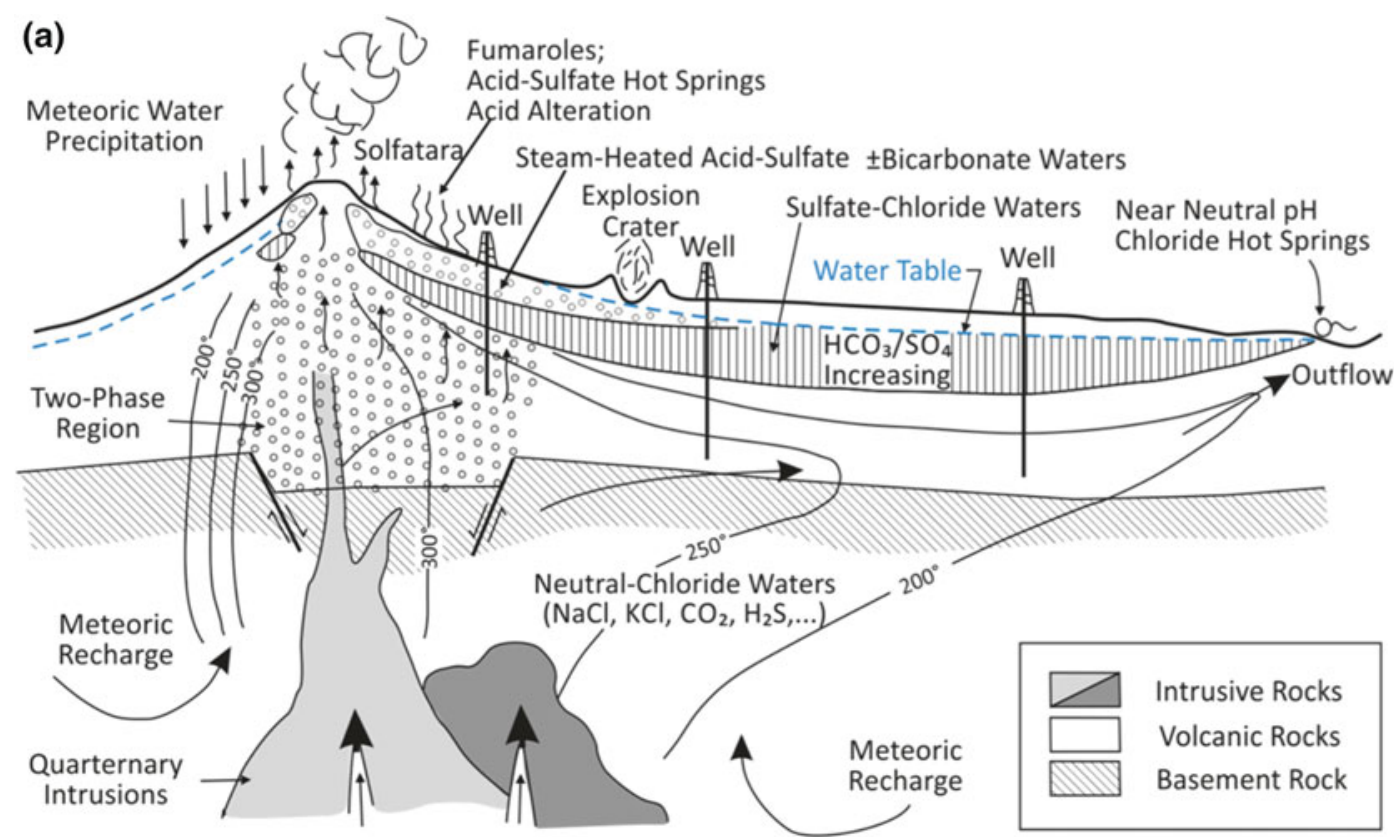

Heat and Mass $\left(\mathrm{HCl}, \mathrm{CO}_{2}, \mathrm{SO}_{2}, \mathrm{H}_{2} \mathrm{O}, \ldots\right)$

Transfer from Magma Systems

(b)

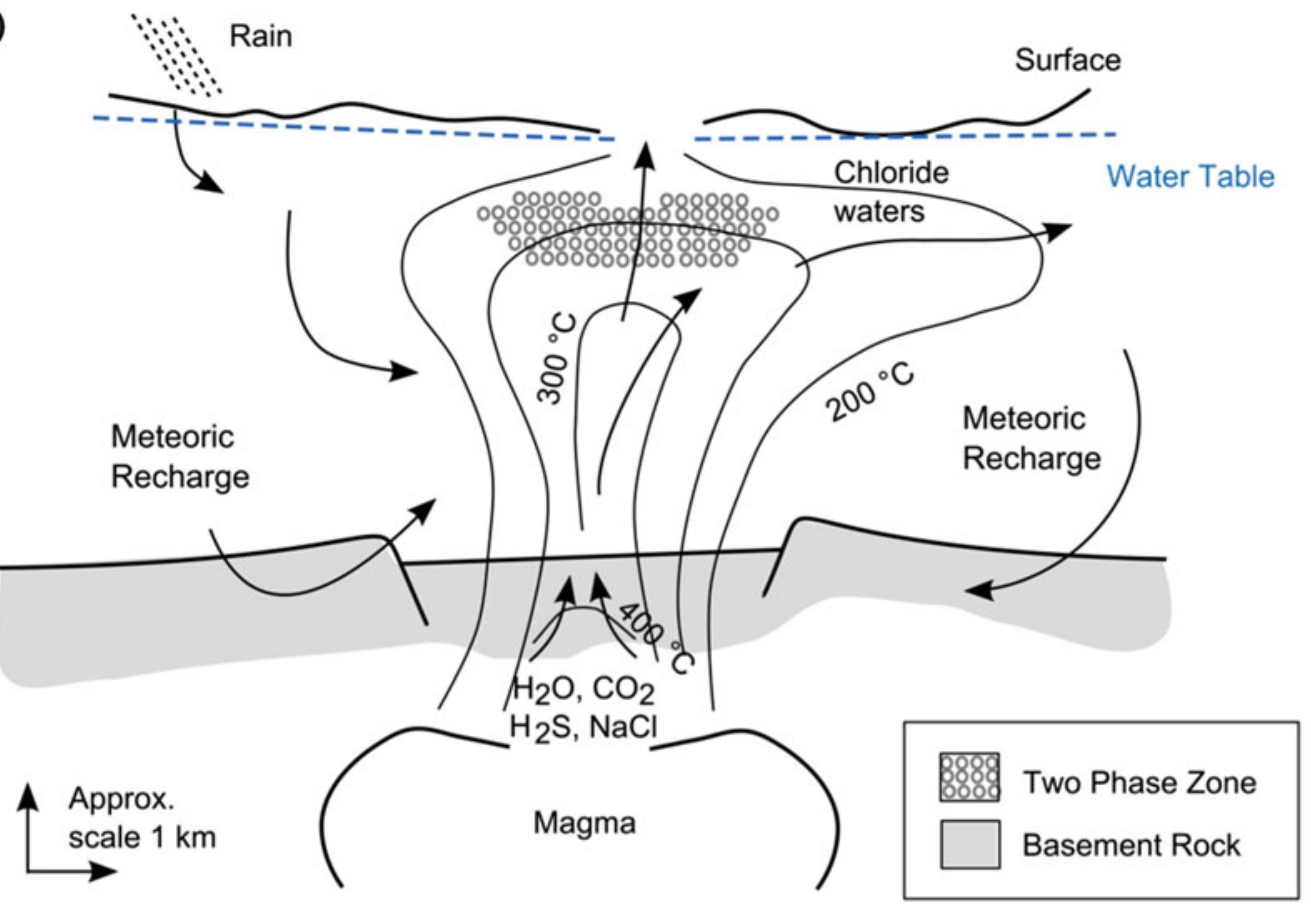

Fig. 1 Conceptual model of a hydrothermal system in, a high-relief volcano (modified after Goff and Janik 2000) and b caldera (modified after Kuhn 2004) 
upper part of the volcano to the surrounding valleys. They can be triggered by gravitational instability (often in response to heavy rainfall), increase in pore pressure, reduction of rock strength, volcano-tectonic earthquake or intrusion of magma. The depressurisation induced by mass movement on the volcanic edifice may also result in the sudden reactivation of the magmatic system.

The waters circulating within volcanic systems are often high-temperature, sometimes supercritical fluids. They interact with the host rock through chemical reactions that result in hydrothermal alteration. The evolution and dynamics of hydrological and volcanic interactions are strongly controlled by fluid flow. This, in-turn, is a function of the pressure, temperature, fluid composition, and, critically, the system's ability to transmit fluids.

\subsection{Fluid flow}

Laminar flow through saturated porous media is described by Darcy's Law (Eq. 1),

$$
q=-\frac{k}{\mu} \frac{d p}{d l}
$$

where $\mathrm{q}$ is specific discharge $(\mathrm{m} / \mathrm{s}), k$ is permeability of the porous media $\left(\mathrm{m}^{2}\right), \mu$ is fluid viscosity (Pa s), and $d P / d l$ is the hydraulic head, or pressure, gradient $(\mathrm{Pa} / \mathrm{m})$ along length $l(\mathrm{~m})$. The fluid viscosity is usually approximated as that of water (liquid or vapour). However, the combined effect of topography and the presence of a deep source of heat and fluids likely produce vast unsaturated (or two-phase) portions within the volcano. Dissolved air and gas near the surface, the phase transition from water (liquid) to vapour due to the temperature gradient, and the decompression of upwelling fluids are some of the processes that produce two-phase (liquid and gas) fluid flow regions within a volcanic system. To extend the Darcy's equation to two phase flow we define the liquid saturation $\left(S_{w}\right)$ as the fraction of a representative bulk volume of the porous medium filled by water and, similarly, the gas saturation $\left(S_{g}\right)$ as the fraction of a representative bulk volume of the porous medium filled by the gas phases, such that (Eq. 2)

$$
S_{g}+S_{w}=1
$$

The capillary pressure $P_{c}$ (in $\mathrm{Pa}$ ) is due to the pressure difference between the two phases (Eq. 3), hence

$$
P_{c}=P_{g}-P_{w}
$$

and is a unique function of water saturation $\left(S_{w}\right)$. Finally, due to the competing flow of the two phases, the relative permeability $(k r)$ is less than or equal to the single phase (usually water) permeability, $k\left(\mathrm{~m}^{2}\right)$, of the medium. We define the relative permeability of the gas phase $\left(k r_{g}\right)$ and the relative permeability of the liquid phase $\left(k r_{w}\right)$ as (Eqs. 4 and 5)

$$
\begin{aligned}
& k r_{g}=\frac{k_{g}}{k} \\
& k r_{w}=\frac{k_{w}}{k}
\end{aligned}
$$

where $k_{g}$ and $k_{w}$ are the effective permeabilities for each of the two fluids. Again the relative permeabilities are assumed to be a unique function of water saturation $\left(S_{w}\right)$. Hence, we define the flow velocity vector $(\mathrm{m} / \mathrm{s})$ of the gas phase along a direction $D(\mathrm{~m})$ as (Eq. 6)

$$
v_{g}=-k \frac{k r_{g}}{\mu_{g}}\left(\nabla P_{g}-\rho_{g} g \nabla D\right)
$$

and similarly the velocity $(\mathrm{m} / \mathrm{s})$ of the water (Eq. 7)

$$
v_{w}=-k \frac{k r_{w}}{\mu_{w}}\left(\nabla P_{w}-\rho_{w} g \nabla D\right)
$$

where $\mu$ and $\rho$ are respectively the viscosity (Pa s) and the density $\left(\mathrm{kg} / \mathrm{m}^{3}\right)$ of the gas $(\mathrm{g})$ and liquid (w) and $g$ is the acceleration $\left(\mathrm{m} / \mathrm{s}^{2}\right)$ due to gravity. Similarly, for non-laminar flow further terms (e.g., Forchheimer term) can be added to Darcy's equation of fluid flow to consider the inertial effects due to turbulence. 


\subsubsection{Permeability and Porosity}

Permeability and porosity are the primary parameters controlling flow and storage of fluids in the subsurface (Manning and Ingebritsen 1999). The permeability also controls the heat regime of the hydrothermal system: high permeabilities $\left(\geq 10^{-14} \mathrm{~m}^{2}\right)$ favour advective transfer of heat away from the igneous source, resulting in low-temperature vapour-dominated systems. Contrastingly, low-permeabilities $\left(<10^{-16} \mathrm{~m}^{2}\right)$ favour slow heat conduction, also producing low-temperature systems. The hottest hydrothermal plumes reside in intermediate permeabilities, around $10^{-15} \mathrm{~m}^{2}$ (Hayba and Ingebritsen 1997). Whilst permeability $(k)$ is an important parameter, it is often one of the least well constrained. It can vary over 17 orders of magnitude, from $\sim 10^{-20} \mathrm{~m}^{2}$ in intact crystalline rocks to $\sim 10^{-9} \mathrm{~m}^{2}$ in porous and fractured basalt (Table 1).

Porosity $(\phi)$, the ratio of voids over total volume (voids and solid) in a given material, defines the storage capacity of the rocks; it also affects permeability and effective thermal conductivity. In many porous and fractured media, there is a positive correlation between $\phi$ and $k$, as permeability is simply the interconnected pore network. Clays and volcanic tuff are unusual in that they can have high porosity values but low permeabilities, at least in part due to their very small particle sizes, propensity to bridge pores and form aggregates (Neuzil 1994). Permeability in such lithology is greatly enhanced by the presence of discontinuities such as fissures, joints, shears and faults that can connect otherwise isolated pores.

Porosity and permeability of volcanic units are primarily controlled by the type of volcanic product (e.g., lava, pyroclastic density current, ash fall) and depositional environment. Inherent heterogeneities between deposits can be enhanced by subsequent compaction, fracturing and chemical alteration. The resulting hydrogeology is complex; hydrological rock properties (porosity, permeability and thermal conductivity) are strongly scale dependent, particularly when fluid flow is focussed along high permeability channels or fractures, as is common in volcanic settings. Such flow pathways themselves are an active component of a dynamic system. Their ability to transmit fluids and therefore the role they play in hydrothermal circulation can be modified by physical changes - the opening or closing of fractures in response to stress-field changes - and chemical alteration, which can both enhance and obstruct fluid flow, as discussed in the next section.

\subsection{Chemical Reactions}

Chemical alteration is an important process within a hydrothermal system. Dissolution can reduce cohesion and weaken a volcanic edifice. This can lead to catastrophic flank collapses and debris avalanches (Reid 2004). Such events can depressurise the magmatic system and trigger an eruption. Conversely, chemical precipitation and deposition processes can cause plugging in areas of intense mineralisation, this can promote pressurisation, which can also lead to flank collapse, as pore pressures increase within the edifice. Such pressurisation can also generate violent steam-driven explosions (Ingebritsen et al. 2010). Chemical dissolution and precipitation processes also alter the host-rock permeability. These processes are sensitive to the thermodynamic conditions and the proportions of different fluid components (Pirajno 2010). Feedbacks between physical and chemical flow behaviour within a hydrothermal system can modify the physical and chemical characteristics of its surface expression - hydrothermal fluid and fumarolic discharge. Therefore, monitoring the hydrothermal discharge can provide clues about the state of volcanic unrest and can even be used to help predict volcanic eruptions (Cronan et al. 1997).

To maximise the value of chemical analysis of hydrothermal discharge as a volcanic monitoring tool, and to fully understand the hazard presented by hydrological and magmatic interactions it is necessary to quantify the rates, spatial distribution and physical effects of chemical alteration within a hydrothermal system. 
Table 1 Measured permeability and porosity ranges for various rock types

\begin{tabular}{|c|c|c|c|}
\hline \multirow[t]{2}{*}{ Rock type } & \multicolumn{2}{|c|}{ Permeability $\left(\mathrm{m}^{2}\right)$} & \multirow{2}{*}{$\begin{array}{l}\text { Porosity }(\%) \\
\text { Range }\end{array}$} \\
\hline & Min & $\operatorname{Max}$ & \\
\hline \multicolumn{4}{|l|}{ Unconsolidated rocks } \\
\hline Gravel & $10^{-10}$ & $10^{-7}$ & $25-40$ \\
\hline Clean sand & $10^{-13}$ & $10^{-9}$ & $5-50$ \\
\hline Silty sand & $10^{-14}$ & $10^{-10}$ & \\
\hline Silt, loess & $10^{-16}$ & $10^{-12}$ & $35-50$ \\
\hline Unweathered clay $^{\mathrm{a}}$ & $10^{-20}$ & $10^{-15}$ & $40-80$ \\
\hline \multicolumn{4}{|l|}{ Consolidated rocks } \\
\hline Shale & $10^{-20}$ & $10^{-16}$ & $0-10$ \\
\hline Unfractured metamorphic and igneous & $10^{-20}$ & $10^{-17}$ & $0-5$ \\
\hline Sandstone & $10^{-17}$ & $10^{-13}$ & $5-35$ \\
\hline Limestone and dolomite & $10^{-16}$ & $10^{-13}$ & $0-20$ \\
\hline Fractured igneous and metamorphic & $10^{-15}$ & $10^{-13}$ & $0-10$ \\
\hline Permeable basalt & $10^{-14}$ & $10^{-9}$ & $0-25$ \\
\hline Karst limestone & $10^{-13}$ & $10^{-9}$ & $5-50$ \\
\hline Fractured basalt & & & $5-50$ \\
\hline Basalt near surface ${ }^{b}$ & $10^{-14}$ & $10^{-12}$ & \\
\hline Basalt at $1 \mathrm{~km}$ depth $^{\mathrm{b}}$ & $10^{-18}$ & $10^{-10}$ & \\
\hline Andesite $^{c}$ & $10^{-20}$ & $10^{-18}$ & $0.2-0.3$ \\
\hline Thermometamorphic $^{\mathrm{d}}$ & $10^{-18}$ & $10^{-14}$ & $2-17$ \\
\hline \multicolumn{4}{|l|}{ Campi Flegrei trachy-phonolite } \\
\hline Tuff, surface ${ }^{\mathrm{e}}$ & $10^{-16}$ & $10^{-15}$ & $48-52$ \\
\hline Tuff, depth ${ }^{\mathrm{e}}$ & $10^{-17}$ & $10^{-15}$ & $19-52$ \\
\hline Chaotic tuff/tuffites $<1 \mathrm{~km}$ depth $^{\mathrm{d}}$ & $10^{-18}$ & $10^{-14}$ & $6-40$ \\
\hline Chaotic tuff/tuffites $>1 \mathrm{~km} \mathrm{depth}{ }^{\mathrm{d}}$ & $10^{-18}$ & $10^{-14}$ & $5-36$ \\
\hline Tuffites $(\mathrm{HT} \text { altered })^{\mathrm{f}}$ & $10^{-16}$ & $10^{-16}$ & $0.05-0.07$ \\
\hline Lava $^{\mathrm{d}}$ & $10^{-18}$ & $10^{-14}$ & $7-25$ \\
\hline \multicolumn{4}{|l|}{ Montserrat andesite } \\
\hline Pyroclastic flow deposit ${ }^{\mathrm{g}}$ & $10^{-18}$ & $10^{-13}$ & \\
\hline $\operatorname{Lava}^{\mathrm{g}}$ & $10^{-17}$ & $10^{-13}$ & \\
\hline Lahar deposit ${ }^{\mathrm{g}}$ & $10^{-14}$ & $10^{-13}$ & \\
\hline
\end{tabular}

Sedimentary rocks are given for comparison. Hydrothermal systems in limestone usually develop as skarn deposit. Data from Freeze and Cherry (1979). ${ }^{a}$ Neuzil (1994), ${ }^{\mathrm{b}}$ Ingebritsen et al. (2006), ${ }^{\mathrm{c}}$ Petrov et al. (2005), ${ }^{\mathrm{d}}$ Piochi et al. (2014), ${ }^{\mathrm{e}}$ Peluso and Arienzo (2007), ${ }^{\text {f }}$ Giberti et al. (2006), ${ }^{\mathrm{g}}$ Hemmings et al. (2015a)

\subsubsection{Reaction Controlling Parameters} Many factors may influence hydrothermal alteration, including temperature, pressure, rock type, fluid flux, fluid composition, and time. The relative importance of each of these has been much discussed in the literature (Gifkins et al. 2005;
Pirajno 2010) and appears to vary between different case studies.

\subsubsection{Fluid Composition}

The dominant form of chemical alteration (dissolution and/or precipitation) is principally a 
function of the composition of the circulating hydrothermal fluids. Meteoric water and seawater are the main sources of fluid in hydrothermal systems with an additional and dynamic contribution of magmatic fluids. The composition of hydrothermal fluid critically affects the mineral-fluid equilibria and therefore the concentration of rock forming elements (RFEs) such as Silica $\left(\mathrm{SiO}_{2}\right)$, Sodium (Na), Potassium $(\mathrm{K})$, Calcium (Ca) and Magnesium (Mg). The mineral-fluid equilibria and solubility of RFEs, as well as sulphate $\left(\mathrm{SO}_{4}{ }^{2-}\right)$, chloride $\left(\mathrm{Cl}^{-}\right)$and bicarbonate $\left(\mathrm{HCO}_{3^{-}}\right)$, is affected by temperature, pressure and water/rock (W/R) ratio as well as the composition of the host rock. These factors also affect kinetic rate of chemical alteration. In addition, the relative mobility of elements depends on the characteristics of fluid flow, the number of phases (liquid and gas) and chemical condition along the flow path including $\mathrm{pH}$, redox condition, sulfidation state, availability of ligands.

The chloride-sulphate-bicarbonate ternary diagram by Giggenbach and Soto (1992) provides a tool to identify water end-members (Fig. 2). It represents graphically the classification of thermal water suggested by Ellis and Mahon (1977) based on major ions, which identifies (i) neutral alkali-chloride waters which result from extensive interaction with the reservoir rocks and may cause silica or carbonate supersaturation at surface condition; (ii) acid-sulphate waters which result from the condensation of volcanic gases into the shallower groundwater system and are often depleted in alkali and $\mathrm{Cl}$ but enriched in metals; (iii) bicarbonate waters which usually show thermodynamic equilibrium with the reservoir rock and are common at the edge of magmatic-hydrothermal systems (Ellis and Mahon 1977; Giggenbach and Soto 1992; Goff and Janik 2000).

\subsubsection{Acidity of Hydrothermal Fluids}

Upper regions of hydrothermal systems are often characterized by steam-heated fumarolic alteration due to the presence of acidic, sulphate-rich fluids (Rye 2005). These fluids may cause leaching of the host rocks, resulting in an increase in both rock porosity and permeability. Eventually extreme acidic fluids $(\mathrm{pH}<2)$ generate the development of vuggy silica and thereby facilitate faster gas escape in the shallow zone (Mayer et al. 2016 and references therein). In the presence of abundant sulphate ions and Al-rich host rocks, within a lesser acidic environment $(\mathrm{pH}>2)$, the formation of alunite dominates (alunitic alteration, Pirajno 2010).
Fig. 2 Classification ternary diagram of thermal waters from Giggenbach and Soto (1992) based on the content of major solutes: $\mathrm{Cl}^{-}, \mathrm{SO}_{4}{ }^{2-}$ and $\mathrm{HCO}_{3-}$. The vertexes represent the alkali-chloride, sulphate and bicarbonate water type end members, whilst the arrows show major differentiation processes

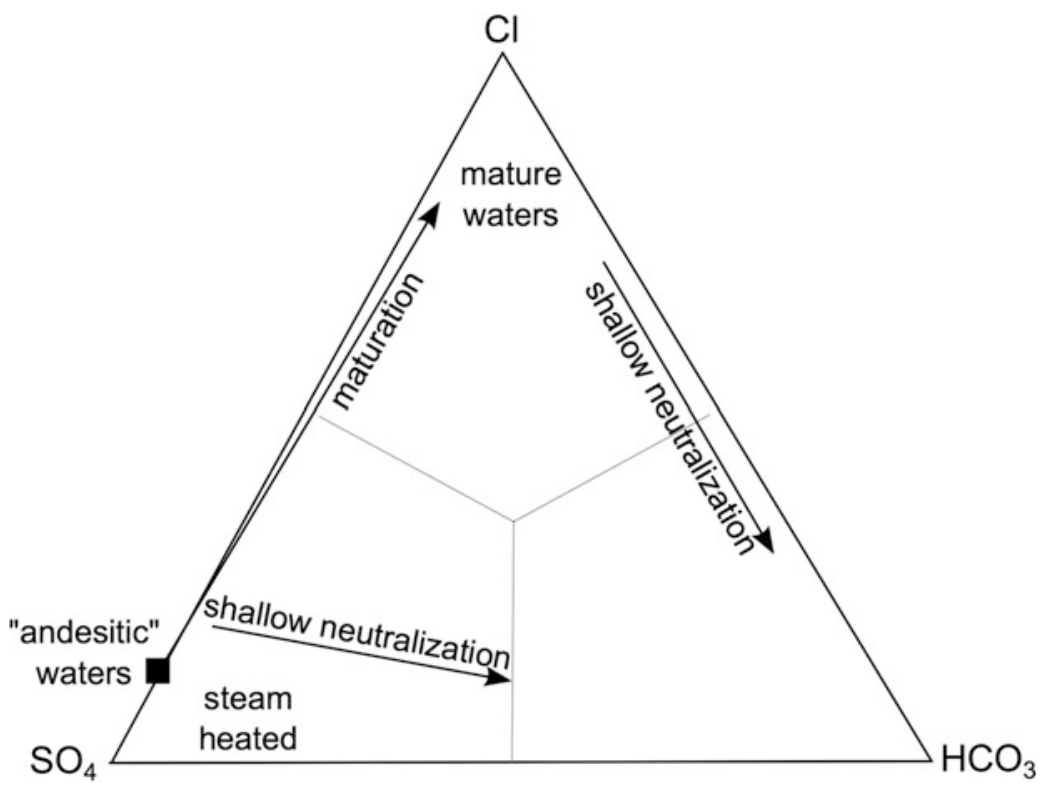


Fig. 3 Conceptual model for the formation of near surface high-sulfidation alteration. $\mathrm{pH}$ and composition control the development of alteration zones with increasing distance to the main fumarolic conduit. A highly permeable, acidic core characterized by amorphous silica is laterally replaced by a zone of alunite and amorphous silica.

Successive neutralization of the fluids promotes the formation of kaolinite. Rock permeability as well as the degree of alteration increase toward the center of the hydrothermal activity (Mayer et al. 2016)

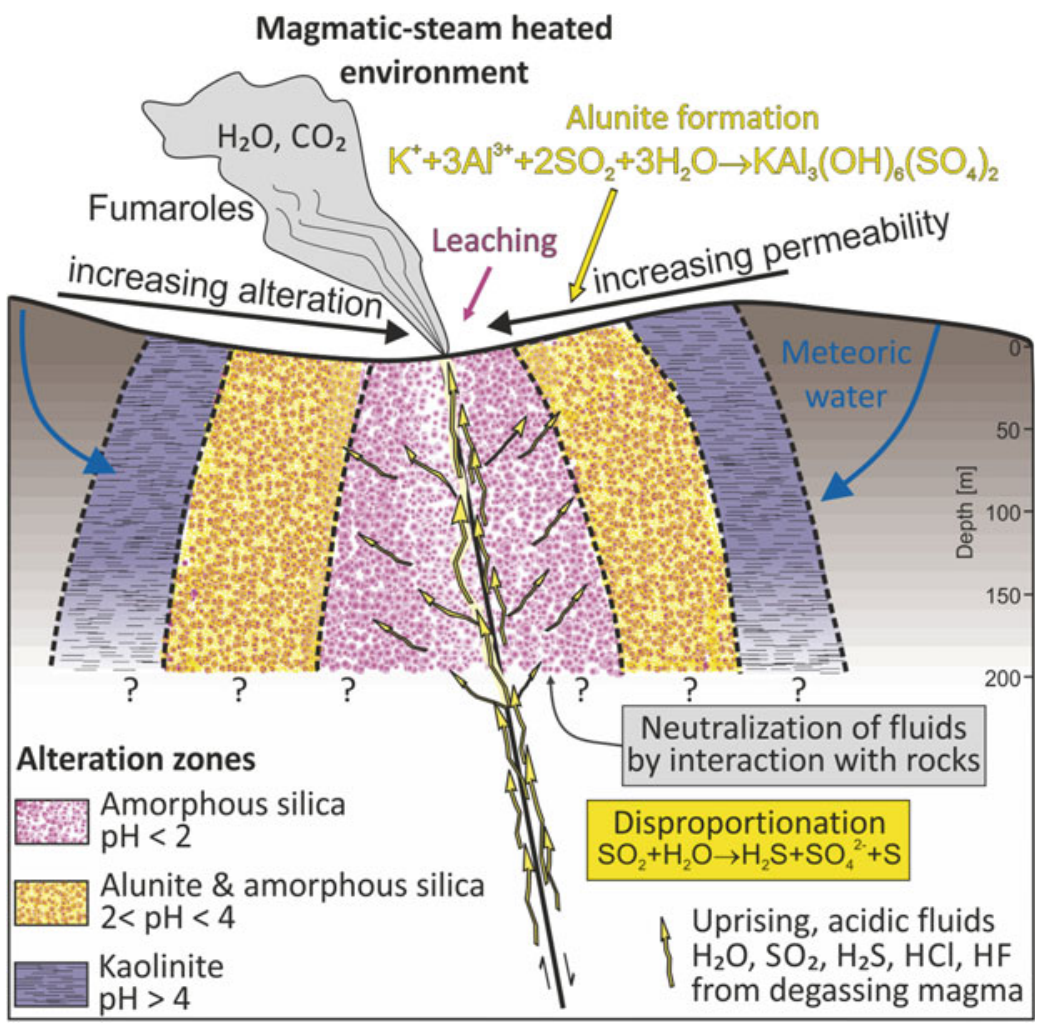

Often the fluids undergo progressive neutralization as they flow away from the degassing vents. This results in a sequence of alteration facies (Fig. 3) from silicic to advanced argillic to intermediate argillic (Fulignati et al. 1998).

In similar environments the distribution of kaolinite and alunite may also be affected by the presence of groundwater. Alunite preferentially forms at or above the groundwater table where atmospheric oxygen could oxidize $\mathrm{H}_{2} \mathrm{~S}$ to $\mathrm{H}_{2} \mathrm{SO}_{4}$, which is required for the formation of alunite (Mutlu et al. 2005).

\subsubsection{Water/Rock Ratio}

The amount of water and the rock surface area available for reactions are two of the primary controls on alteration. Therefore, the Water/Rock $(\mathrm{W} / \mathrm{R})$ ratio and rock porosity and permeability will determine the type and extent of alteration. $\mathrm{W} / \mathrm{R}$ ratios range between 0.1 and 0.4 (Henley and Ellis 1983) while porosity can vary from 0 to $\sim 80 \%$ (Freeze and Cherry 1979; Neuzil 1994). Static systems, with low porosity and low
W/R ratios, are termed "closed systems", or "rock dominated systems". In this case, the secondary minerals depend nearly entirely on temperature and are of similar chemical composition to the original rocks, although possibly in a hydrated form (typical of propylitic alteration, see below). The alteration minerals often resemble those due to metamorphism (Giggenbach 1984).

Most hydrothermal systems are, however, "open systems", or "liquid dominated systems", which are characterised by high W/R ratios. In these cases, the fluid composition has a greater importance. The minerals that precipitate in open systems are the result of alteration by mobile fluids of constantly changing composition. In these systems permeability is highly influential and systematic spatial patterns of alteration zoning are common.

\subsubsection{Rock Type}

Many studies support the assumptions that the chemical and mineralogical composition of the original rock will change the composition of the 
equilibrium solution and therefore the rate of individual dissolution/precipitation reactions (e.g. Pirajno 2010). Consequently, various investigations have attempted to assess the most easily altered minerals in the host rocks (e.g. Browne 1984). Glass, followed by olivine are the least stable phases at surface conditions, as such basalts are likely to alter more rapidly than felsic rocks. Numerous studies of basalt dissolution have shown that the presence of glass can increase dissolution rates (Wolff-Boenisch et al. 2006; Berger et al. 1994; Stefansson and Gislason 2001; Zakharova et al. 2007; Hu et al. 2010; Gudbrandsson et al. 2011). However, experimental results on the alteration of volcanic materials are biased by the dominant use of basalt as starting material.

Even though basaltic glass dissolves relatively rapidly, basalts are still low-silica magmas, and therefore silica concentrations remain higher in felsic rocks. Browne (1978) showed that, at temperatures above $280{ }^{\circ} \mathrm{C}$, the host rock composition has a negligible effect on alteration minerals. Indeed, he gathered evidence of the same stable alteration assemblages in basalts, sandstones, rhyolites and andesites. Most accessible hydrothermal systems, however, are at temperatures below $280{ }^{\circ} \mathrm{C}$ and in such systems Browne (1978) reports high-silica zeolites in rhyolitic volcanoes, and low-silica zeolites in basaltic and andesitic systems.

\subsubsection{Pressure}

Pressure generally has a secondary role in hydrothermal alteration (Robb 2005). An important exception is the role of pressure in controlling boiling in hydrothermal environments. Boiling at depth leads to low-salinity vapour and high-salinity brine. This phase separation is responsible for transport and deposition of elements that are key to ore mineralization (Henley and Berger 2013). In the upper $\sim 400 \mathrm{~m}$, pressure is due to the weight of the hot, possibly vapour rich, water column leading to pressure gradient below hydrostatic. At the margin of the hydrothermal system mixing between cold and hot water is enhanced by the pressure difference (Henley 1985). At greater depth, pressures exceed hydrostatic, feeding the upper reservoir (Henley
1985). Sharp pressure gradients can occur between high and low permeability portions of a hydrothermal system, for example within the flow system feeding fumaroles. Major processes occur at the interface of liquid-gas phases, such as massive precipitation of minerals (Lu and Kieffer 2009). In addition, high pressures can cause rock compaction, thus reduce permeability and drive pressure solution. Conversely, rapid increase in fluid pressure can promote fracturing leading to increases in permeability.

\subsubsection{Temperature}

Temperature, on the other hand, controls the general alteration patterns of hydrothermal systems because it is the main control on mineral solubility (Giggenbach 1988; Oelkers et al. 2009). For example, metal chlorides and alkaline minerals are more soluble at high temperatures, while gypsum, anhydrite, calcite and dolomite show retrograde solubility below $\sim 100{ }^{\circ} \mathrm{C}$ (Frazer 2014). Silica solubility increases as temperatures rise, until $\sim 300{ }^{\circ} \mathrm{C}$. With further temperature increases, silica solubility decreases (Fournier 1985). These types of thermodynamic relationships in single-phase hydrothermal systems are relatively well constrained, and are reviewed in detail by Oelkers et al. (2009).

\section{Hydrothermal Systems and Unrest}

Many of the conditions that control fluid flow and chemical alteration are modified by the re-activation of the magmatic system, and evolve during volcanic unrest. For example, the introduction of fresh magma into the deep portions of an active hydrothermal system can critically change the pressure and temperature conditions within the system, thus leading to the development of gas pockets in the subsurface (Jasim et al. 2015). This can rapidly lead to phreatic eruptions. Thus it is crucial to expand unrest tracking to include monitoring of non-magmatic hazards (Sandri et al. 2017-this volume).

Seismicity, gases and ground deformation are usually monitored around active and restless 
volcanoes (Sparks 2003). Gravity anomaly studies (Gottsmann et al. 2008; Coco et al. 2016) and acoustic waves (Ferrazzini and Aki 1987) also provide insight into subsurface processes. Measurements of water chemistry composition from hydrothermal manifestation such as boiling pools, crater lakes and thermal springs are also routinely conducted (Varekamp et al. 2001, 2009; Federico et al. 2002; Tassi et al. 2003). The increase of Rare Earth Elements (REE)/Cl, RFEs (e.g., $\mathrm{Ca}, \mathrm{Mg}, \mathrm{K}) / \mathrm{Cl}$ and the increase in $\mathrm{SiO}_{2}$ concentration are indicative of either intrusion of fresh magma within the hydrothermal reservoir or exposure to water/rock interaction of fresh rock due to hydrofracturing (Varekamp et al. 2008). A pH drop and temperature increase in spring water can also be indicative of an increase in magmatic activity. However the majority of springs in volcanic environment are fed by the regional groundwater reservoirs, thus representing the cooler water inflow of the hydrothermal system (Jasim 2016). Thermal waters are focused on fluid upwelling pathways such as faults and fractures (Curewitz and Karson 1997; Hemmings et al 2015b; Jasim et al. 2015).

The influx of magmatic fluids can manifest as changes in chemical compositions of hydrothermal discharges. In particular the strong field ligands $\mathrm{Cl}^{-}$and $\mathrm{F}^{-}$, from magmatic degassing, can mobilize metals and $\mathrm{F}^{-}$greatly enhances the dissolution rates of aluminium silicates (Oelkers and Gislason 2001; Wolff-Boenisch et al. 2004) with detrimental effect on rock mechanical properties. However, along the upwelling flow path, mixing with surface waters and chemical reactions with the rock often occur, overprinting the magmatic signature. Magmatic gases and vapour either mix with deep circulating water (Giggenbach 1988) or they condense to form in situ thermal waters (Rye 1993). In both cases, they rapidly dissociate and form a strong acidic solution which causes cation leaching of the host rock leading to advanced argillitic alteration (Giggenbach 1988; Symonds et al. 2001). Prior to mineral precipitation, the resulting waters are enriched in $\mathrm{Si}, \mathrm{Na}^{+}, \mathrm{K}^{+}, \mathrm{Mg}^{2+}$ and $\mathrm{Ca}^{2+}$, and other metals, proportionally to their concentrations in the host rock (rock congruent dissolution) until the solution is more or less neutralised. This is therefore called the "primary neutralisation zone". Continued acid leaching in K-feldspar systems leads invariably to the formation of alunite, an important component of high-sulfidation epithermal systems, where it can replace entire masses of rocks. For example, alunite can be formed indirectly from K-feldspar through the formation of K-mica and kaolinite (Eqs. 8a-8c).

$$
\begin{aligned}
& 3 \mathrm{KAlSi}_{3} \mathrm{O}_{8}+2 \mathrm{H}^{+} \rightarrow \mathrm{KAl}_{3} \mathrm{Si}_{3} \mathrm{O}_{10}(\mathrm{OH})_{2}+2 \mathrm{~K}^{+}+6 \mathrm{SiO}_{2} \\
& \text { K-feldspar K-mica } \\
& \mathrm{KAl}_{3} \mathrm{Si}_{3} \mathrm{O}_{10}(\mathrm{OH})_{2}+2 \mathrm{H}^{+}+3 \mathrm{H}_{2} \mathrm{O} \rightarrow 3 \mathrm{Al}_{2} \mathrm{Si}_{2} \mathrm{O}_{5}(\mathrm{OH})_{4}+2 \mathrm{~K}^{+} \\
& \mathrm{K} \text {-mica } \\
& \text { Kaolinite } \\
& 3 \mathrm{Al}_{2} \mathrm{Si}_{2} \mathrm{O}_{5}(\mathrm{OH})_{4}+2 \mathrm{~K}^{+}+6 \mathrm{H}^{+}+4 \mathrm{SO}_{4}{ }^{2-} \rightarrow 2 \mathrm{KAl}_{3}\left(\mathrm{SO}_{4}\right)_{2}(\mathrm{OH})_{6}+6 \mathrm{SiO}_{2}+3 \mathrm{H}_{2} \mathrm{O} \\
& \text { Kaolinite } \\
& \text { Alunite }
\end{aligned}
$$


Most field and experimental observations imply that permeability in hydrothermal systems tends to decrease with time. However, most of these systems remain active for long periods of time (typically $10^{3}-10^{6}$ years, Ingebritsen et al. 2010). Mechanisms must exist by which permeable pathways are maintained and or developed to allow continuing circulation of hydrothermal fluids and ongoing alteration. Such mechanisms include: (i) the periodic re-organisation of flow patterns related to spatial variations in dissolution and precipitation behaviour (Ritchie and Pritchard 2011); (ii) the dissolution of minerals because of pulses of acidic fluids (Plumlee 1999); (iii) feedback between permeability reduction, fluid pressure and rock mechanics resulting in hydrofracturing, shear dislocation, mineral dissolution and the opening of flow pathways (Barnes 2015; Weis 2015); (iv) pulsating volcanic activity causing fracturing, periodic variations in temperature, pressure and the composition of the circulating fluids (Bodnar et al. 2007); (v) Cooling of the magmatic sills and dikes may lead to thermal cracking (Cathles et al. 1997) and the thermal expansion of the rock; both of which cause increases in fracture density (Chen et al. 1999) enhancing rock permeability; and (vi) stressed induced fracturing (Tapponnier and Brace 1976). Furthermore, fluid pathways often ease the movement of magma towards the surface as shown by the 1975-1984 volcano-tectonic crisis at Krafla caldera (Iceland), which lead to the emplacement of fault-controlled pseudodikes at shallow depths $(<100 \mathrm{~m})$ and eruptive events (Opheim and Gudmundsson 1989).

The evolution of a hydrothermal system involves the interplay between a number of mechanisms, physical and chemical, that operate at very different timescales ranging from seconds to hundreds of years. Where volcanic unrest results in rapid modification of the hydrothermal system, hazards associated with unrest can manifest rapidly, with limited warning or precursory activity. Dynamic changes in permeability, related to rapid mineral precipitation or opening of fractures can immediately modify flow pathways. This can result in dramatic changes in heat and fluid flow, near surface pressurisation, hydrothermal outflow and phreatic explosions. Even slow processes such as the incremental development of pervasive alteration zones can manifest as a dynamic hazard in response to continued or future unrest, as strong crystalline rocks are hydrothermally altered into weak secondary clays.

\section{Monitoring and Signals}

The dynamic hydrological and hydrothermal response to volcanic unrest means that, boreholes, springs, fumaroles, crater lakes and geophysical imaging of the hydrological system can provide a rare window into the state of a volcano and the evolution of volcanic hazard. Hydrological monitoring itself is multi-parametric; insights can be gained from exploring physical and chemical patterns. For instance, the effect of groundwater on volcanic gases changes according to their solubility. As such, a larger proportion of $\mathrm{SO}_{2}, \mathrm{HCl}$ and $\mathrm{HF}$ emitted from magma remain in solution in water compared to $\mathrm{CO}_{2}$ and $\mathrm{H}_{2} \mathrm{~S}$. Hence, $\mathrm{SO}_{2}, \mathrm{HCl}$ and $\mathrm{HF}$ can be detected at the surface, only during intense magmatic activity or after drying of degassing pathways (Symonds et al. 2001). In the absence of active degassing, the isotopic ratio of the gases dissolved in groundwater2 such as ${ }^{3} \mathrm{He} /{ }^{4} \mathrm{He}$ (positive) and $\delta^{13} \mathrm{C}$ (negative) can be indicative of a magmatic source (Sorey et al. 1998; Allard et al. 1997; Federico et al. 2002).

Fluctuations of the water table/spring discharge have also been frequently recorded before the onset of magmatic activity and are often interpreted as the effect of opening and closing of fractures during the intrusion of fresh magma (Tanguy 1994; Shibata and Akita 2001; Newhall et al. 2001). Alternatively, the effect of the water phase transition from liquid to gas at relatively shallow $(<2 \mathrm{~km})$ depth may also cause uplift of the water table (Jasim et al. 2015). Water levels in boreholes can be relatively easily monitored and have been observed to respond to tectonic and volcanic perturbations in a range of volcanic settings (e.g. Usu Volcano, Japan; Kilauea Volcano, Hawai'i; Koryajskii Volcano, Kamchatka). 
Level changes have been attributed to thermal pressurisation, compression of water saturated rocks and opening of fractures in response to the intrusion of magma. However, the magnitude and even the sign of this hydrological response is a complex function of the nature of the thermal and mechanical perturbation, the orientation and connectivity of permeable pathways and even the design of the well itself. Thus, interpreting such signals in relation to magmatic unrest requires some prior understanding of the hydrological features involved.

Spring discharge fluctuations are harder to measure than well water level changes, especially on the flanks of volcanoes experiencing unrest, and are therefore less well documented. Decline in non-thermal spring discharge on Centre Hills, Montserrat, were observed prior to the onset of volcanic activity at the adjacent Soufrière Hills Volcano in 1995. This was followed by an increase after the cessation of the second eruptive phase in 2004 (Hemmings et al. 2015a). The mechanism behind such fluctuation is unclear, it may relate to fracture dynamics associated with magmatic pressurisation (and depressurisation). Regular temperature measurement and chemical analysis of spring systems and hydrological lakes in volcanic settings can provide insights into the differences and changes in flow pathways related to magmatic perturbation.

Chemical analysis of thermal springs and fumaroles are more common hydrological/hydrothermal monitoring strategies employed at active volcanoes. Changes in chemical composition and isotopic concentrations are often related to changes in the relative contribution of magmatic fluids to other groundwater species. Although there are general indicators for increased magmatic fluid contribution to discharging hydrothermal fluids, effective use of spring temperature, chemistry and discharge data as volcanic unrest monitoring tools requires a good understanding of the underlying composition of the hydrological and hydrothermal features and the likely sensitivity to different perturbation scenarios, in specific volcanic areas. For example, Taran et al. (2008) proposed that lower flowing, acidic springs at El Chichón volcano, Mexico would make a better monitoring target than near-neutral, high discharge springs. Potential chemical indicators of unrest in these springs include increase in relative concentration of $\mathrm{Mg}$, and increase in $\mathrm{Cl} / \mathrm{B}$ and $\mathrm{Cl} / \mathrm{Br}$ ratios.

In summary, the physical and chemical signals or hydrological perturbation associated with magmatic unrest are complex and site dependant. Relative contributions of different fluid components and their interaction with existing flow pathways, can determine how a system evolves during quiescent periods. This evolution dictates the likely response to thermodynamic and chemical perturbation associated with the initiation of volcanic unrest. Given the intricate feedbacks between magma, hydrology and hazards and the sudden changes of the systems involved, only high-frequency (hour-week) monitoring of temperature, $\mathrm{pH}$, electrical conductivity of water, depth of the water table, REE, rock forming elements and dissolved gas coupled with geophysical monitoring can untangle the evolution of the magmatic system, the opening/closure of fractures and the seasonal groundwater dynamic.

\section{Open Questions-Important Unknowns}

We have established that circulating hydrothermal fluids are highly reactive and may result in precipitation of alteration products or dissolution of the host rock, both of which may cause porosity, and permeability changes. However, the precise nature of this alteration varies with fluid chemistry, rock mineralogy and thermodynamic conditions. This uncertainty in alteration makes predicting the impact of water/rock interaction (WRI) on porosity and permeability, and therefore on fluid flow, particularly challenging. The background fluid flow regime is a critical part of the local expression of heat-flow as well as pressure distribution that surrounds a magmatic system. As such it may exercise an important control over the dynamics of the magmatic system that is currently poorly understood. Data constraining the time scales over which hydrothermal alteration occurs, related to 
data gathered from long term monitoring of coupled magmatic-hydrothermal systems, are thus crucial to inform ongoing interpretations and further predictions of areas experiencing magmatic-hydrothermal unrest.

Acknowledgements The authors thank Shaul Hurwitz for his constructive comments during the review of this manuscript and Pablo Palacios for carefully editing the extended abstract. This project has received funding from the European Union's Seventh Program for research, technological development, and demonstration under grant agreement no. 282759 (VUELCO). K. Mayer and B. Scheu also acknowledge the support of a PROCOPE grant (Hot Hydrothermal Volcanic Systems; project-ID 57130387), funded and implemented by the Deutscher Akademischer Austauschdienst (DAAD) in Germany, and the Ministry of Foreign and European Affairs (MAE) and the Ministry of Higher Education and Research (MESR) in France. K. Mayer and B. Scheu acknowledge the support of the ERC Advanced Investigator Grant (EVOKES - no. 247076).

\section{Glossary}

Hydrothermal system A groundwater system that has an area of recharge, an area of discharge, and a heat source. When a magma supplies the heat source and volatiles, the hydrothermal system is termed a magmatic hydrothermal system

Hydrothermal alteration hydrothermal alteration is a complex process involving chemical, mineralogical, and textural changes, due to the interaction of hot aqueous fluids and the host rocks through which they circulate

Permeability Connected pore space of a rock or lithology, controlling fluid flow within a reservoir

Porosity Ratio of voids over the total volume of the rock with respect to a reference rock-volume

Water/rock interaction (WRI) The set of chemical reactions between aqueous fluids and rocks. These reactions modify both the chemistry of the circulating fluid and the mineralogy of the host rock

Fluid generic term for either liquid or gas or both
Liquid liquid state of matter (e.g., water)

Gas gas state of matter (e.g., vapour)

Water table level below which water saturation occurs

\section{References}

Aizawa K (2008) Classification of self-potential anomalies on volcanoes and possible interpretations for their subsurface structure. J Volcanol Geoth Res 175:253268

Allard P, Jean-Baptiste P, D'Alessandro W, Parello F, Parisi B, Flehoc C (1997) Mantlederived helium and carbon in groundwaters and gases of Mount Etna, Italy. Earth Planet Sci Lett 148:501-516

Barnes H (2015) Hydrothermal processes: the development of geochemical concepts in the latter half of the twentieth century. Geochem Perspect 4:1-93

Berger G, Claparols C, Guy C, Daux V (1994) Dissolution rate of a basalt glass in silica-rich solutions: implications for long-term alteration. Geochim Cosmochim Acta 58:4875-4886

Bodnar RJ, Cannatelli C, De Vivo B, Lima A, Belkin HE, Milia A (2007) Quantitative models for magma degassing and ground deformation (bradyseism) at Campi Flegrei, Italy: implications for future eruptions. Geology 35:791-794

Browne PRL (1978) Hydrothermal alteration in active geothermal fields. Annu Rev Earth Planet Sci 6: 229-250

Browne PRL (1984) Subsurface stratigraphy and hydrothermal alteration of Eastern section of the Olkaria geothermal field, Kenya. In: Proceedings of the 6th New Zealand geothermal workshop, vol 1, pp 33-41

Bruno PPG, Ricciardi GP, Petrillo Z, Di Fiore V, Troiano A, Chiodini G (2007) Geophysical and hydrogeological experiments from a shallow hydrothermal system at Solfatara Volcano, Campi Flegrei, Italy: response to caldera unrest. J Geophys Res: Solid Earth 112:1-17

Cabrera MC, Custodio E (2004) Groundwater flow in a volcanic-sedimentary coastal aquifer: Telde area, Gran Canaria, Canary islands, Spain. Hydrogeol J 12: 305-320

Cathles LM, Erendi AHJ, Barrie T (1997) How long can a hydrothermal system be sustained by a single intrusive event? Econ Geol 92:766-771

Chen Y, Xiaodong W, Fuqing Z (1999) Experiments on thermal fracture in rocks. C Sci Bull 17:1610-1612

Chiodini G, Frondini F, Cardellini C, Granieri D, Marini L, Ventura G (2001) $\mathrm{CO}_{2}$ degassing and energy release at Solfatara volcano, Campi Flegrei, Italy. J Geophys Res 106:16213-16221 
Christiansen LB, Hurwitz S, Saar MO, Ingebritsen SE, Hsieh P (2005) Seasonal seismicity at western United States volcanic centers. Earth Planet Sci Lett 240: 307-321

Coco A, Gottsmann J, Whitaker F, Rust A, Currenti G, Jasim A, Bunney S (2016) Numerical models for ground deformation and gravity changes during volcanic unrest: simulating the hydrothermal system dynamics of an active caldera. Solid Earth Discussions 7:557-577

Cronan DS, Johnson AG, Hodkinson RA (1997) Hydrothermal fluids may offer clues about impending volcanic eruptions. Eos 78:341-345

Cruz JV, Oliveira Silva M (2001) Hydrogeologic framework of Pico Island, Azores, Portugal. Hydrogeol J 9:177-189

Curewitz D, Karson JA (1997) Structural settings of hydrothermal outflow: fracture permeability maintained by fault propagation and interaction. J Volcanol Geoth Res 79:149-168

Custodio E (2007) Groundwater in volcanic hard rocks. In: Krasny and Sharp (eds) Groundwater in fractured rocks. IAH Selected Paper Series, vol 9, pp 95-108

Ellis AJ, Mahon WAJ (1977) Chemistry and geothermal systems. Academic Press (392)

Federico C, Aiuppa A, Allard P, Bellomo S, Jean-Baptiste P, Parello F, Valenza M (2002) Magma-derived gas influx and water-rock interactions in the volcanic aquifer of Mt. Vesuvius, Italy. Geochimica et Cosmochimica Acta 66:963-981

Ferrazzini V, Aki K (1987) Slow waves trapped in a fluid-filled infinite crack: implications for volcanic tremor. J Geophys Res 92:9215-9223

Finn C, Williams DL (1987) An aeromagnetic study of Mount St. Helens. J Geophys Res: Solid Earth 92:10194-10206

Finn CA, Sisson TW, Deszcz-Pan M (2001) Aerogeophysical measurements of collapse-prone hydrothermally altered zones at Mount Rainier volcano. Nature 409:600-603

Fournier RO (1985) The behavior of silica in hydrothermal solutions. In: Berger and Bethke (eds) Geology and geochemistry of epithermal systems. Reviews in Economic Geology, vol 2, pp 45-61

Fournier RO (1999) Hydrothermal processes related to movement of fluid from plastic into brittle rock in the magmatic-epithermal environment. Econ Geol 94:1193-1211

Fournier N, Witham F, Moreau-Fournier M, Bardou L (2009) Boiling Lake of Dominica, West Indies: high-temperature volcanic crater lake dynamics. J Geophys Res 114:1-17

Frazer AM (2014) Advances in understanding the evolution of diagenesis in carboniferous carbonate platforms: insights from simulations of palaeohydrology, geochemistry, and stratigraphic development. PhD Thesis, University of Bristol, UK (261)

Freeze R, Cherry J (1979) Groundwater. Prentice Hall (604)
Fulignati P, Gioncada A, Sbrana A (1998) Geologic model of the magmatic hydrothermal system of vulcano (Aeolian Islands, Italy). Mineral Petrol 62:195-222

Giberti G, Yven B, Zamora, M, Vanorio T (2006) Database on laboratory measured data on physical properties of rocks of Campi Flegrei volcanic area (Italy). In: Zollo, Capuano, Corciulo (eds) Geophysical exploration of the Campi Flegrei (Southern Italy) Caldera' interiors: data, methods and results, vol 1, pp 179-192

Gifkins CC, Herrmann W, Large RR (2005) Altered volcanic rocks: a guide to description and interpretation. Ph.D. thesis, University of Tasmania, Australia (275)

Giggenbach WF (1984) Mass transfer in hydrothermal alteration systems - A conceptual approach. Geochim Cosmochim Acta 48:2693-2711

Giggenbach WF (1988) Geothermal solute equilibria. Derivation of Na-K-Mg-Ca geoindicators. Geochim Cosmochim Acta 52:2749-2765

Giggenbach WF, Soto RC (1992) Isotopic and chemical composition of water and steam discharges from volcanic-magmatic-hydrothermal systems of the Guanacaste Geothermal Province, Costa Rica. Appl Geochem 7:309-332

Goff F, CJ Janik (2000) Geothermal systems. In: Sigurdsson, Houghton, McNutt, Rymer, Stix (eds) Encyclopedia of volcanoes, vol 1, pp 817-834

Gottsmann J, Camacho AG, Martí J, Wooller L, Fernández J, Garcia A, Rymer H (2008) Shallow structure beneath the Central Volcanic Complex of Tenerife from new gravity data: implications for its evolution and recent reactivation. Phys Earth Planet Inter 168:212-230

Gudbrandsson S, Wolff-Boenisch D, Gislason SR, Oelkers EH (2011) An experimental study of crystalline basalt dissolution from $2<\mathrm{pH}<11$ and temperatures from 5 to 75 C. Geochim Cosmochim Acta 75:54965509

Hayba D, Ingebritsen S (1997) Multiphase groundwater flow near cooling plutons. J Geophys Res 102:1223512252

Hedenquist J, Lowenstern J (1994) The role of magmas in the formation of hydrothermal ore deposits. Nature 370:519-527

Hemmings B, Whitaker F, Gottsmann J, Hughes A (2015a) Hydrogeology of montserrat, review and new insights. J Hydrol: Reg Stud 3:1-30

Hemmings B, Gooddy D, Whitaker F, Darling GW, Jasim A, Gottsmann J (2015b) Groundwater recharge and flow on Montserrat, West Indies: insights from groundwater dating. J Hydrol: Reg Stud 4:611-622

Henley RW (1985) The geothermal framework of epithermal deposits. Rev Econ Geol 2:1-24

Henley RW, Berger BR (2013) Nature's refineries metals and metalloids in arc volcanoes. Earth Sci Rev 125:146-170 
Henley R, Ellis A (1983) Geothermal Systems Ancient and Modern: a Geochemical Review. Earth Sci Rev 19:1-50

Hu SM, Zhang RH, Zhang XT, Huang WB (2010) Experimental study of water-basalt interactions in Luzong volcanic basin and its applications. Acta Petrologica Sinica 26:2681-2693

Ingebritsen SE, Scholl MA (1993) The hydrogeology of Kilauea volcano. Geothermics 22:255-270

Ingebritsen S, Ward S, Neuzil C (2006) Groundwater in geologic processes. Cambridge University Press (564)

Ingebritsen SE, Geiger S, Hurwitz S, Driesner T (2010) Numerical simulation of magmatic hydrothermal systems. Rev Geophys 48:1-33

Jasim A (2016) Exploring the complexity of groundwater flow in volcanic terrains: a combined numerical, experimental and field data approach. Ph.D. thesis, University of Bristol, UK (199)

Jasim A, Whitaker FF, Rust AC (2015) Impact of channelized flow on temperature distribution and fluid flow in restless calderas: insight from Campi Flegrei caldera, Italy. J Volcanol Geoth Res 303:157-174

Join JL, Folio JL, Robineau B (2005) Aquifers and groundwater within active shield volcanoes. Evolution of conceptual models in the Piton de la Fournaise volcano. J Volcanol Geoth Res 147:187-201

Kuhn M (2004) Reactive flow modeling of hydrothermal systems. Springer, Berlin (264)

Lu X, Kieffer S (2009) Thermodynamics and mass transport in multicomponent, multiphase $\mathrm{H}_{2} \mathrm{O}$ systems of planetary interest. Annu Rev Earth Planet Sci 37:449-477

Manning C, Ingebritsen S (1999) Permeability of the continental crust: Implications of geothermal data and metamorphic systems. Rev Geophy 37:127-150

Mason BG, Pyle DM, Dade WB, Jupp T (2004) Seasonality of volcanic eruptions. J Geophys Res: Solid Earth 109:1-12

Mayer K, Scheu B, Montanaro C, Yilmaz TI, Isaia R, Aßbichler D, Dingwell DB (2016) Hydrothermal alteration of surficial rocks at Solfatara (Campi Flegrei): Petrophysical properties and implications for phreatic eruption processes. J Volcanol Geoth Res 320:128-143

Mutlu H, Sariiz K, Kadir S (2005) Geochemistry and origin of the Şaphane alunite deposit, Western Anatolia, Turkey. Ore Geol Rev 26:39-50

Neuzil CE (1994) How permeable are clays and shales? Water Resour 30:145-150

Newhall CG, Albano SE, Matsumoto N, Sandoval T (2001) Roles of groundwater in volcanic unrest. J Geol Soc Philippines 56:69-84

Oelkers EH, Gislason SR (2001) The mechanism, rates and consequences of basaltic glass dissolution: I. An experimental study of the dissolution rates of basaltic glass as a function of aqueous $\mathrm{Al}, \mathrm{Si}$ and oxalic acid concentration at $25 \mathrm{C}$ and $\mathrm{pH}=3$ and 11 . Geochim Cosmochim Acta 65:3671-3681
Oelkers EH, Benezeth P, Pokrovski GS (2009) Thermodynamic databases for water-rock interaction. In: Oelkers and Schott (eds) Thermodynamics and kinetics of water-rock interaction. Reviews in Mineralogy and Geochemistry, 70, 1-37

Opheim JA, Gudmundsson A (1989) Formation and geometry of fractures, and related volcanism, of the Krafla fissure swarm, northeast Iceland. Geol Soc Am Bull 101:1608-1622

Peluso F, Arienzo I (2007) Experimental determination of permeability of Neapolitan Yellow Tuff. J Volcanol Geoth Res 160:125-136

Peterson FL (1972) Water development on tropic volcanic islands-type example: Hawaii. Ground Water 10:18-23

Petrov VA, Poluektov VV, Zharikov AV, Velichkin VI, Nasimov RM, Diaur NI, Terentiev VA, Shmonov VM, Vitovtova VM (2005) Deformation of metavolcanics in the Karachay Lake area, Southern Urals: petrophysical and mineral-chemical aspects. Geol Soc London, Spec Publ 240:307-322

Piochi M, Kilburn CRJ, Di Vito MA, Mormone A, Tramelli A, Troise C, De Natale G (2014) The volcanic and geothermally active Campi Flegrei caldera: an integrated multidisciplinary image of its buried structure. Int J Earth Sci 103:401-421

Pirajno F (2010) Hydrothermal processes and mineral systems. Springer, Berlin (1250)

Plumlee GS (1999) The environmental geology of mineral deposits. In: Plumlee and Logsdon (eds) The Environmental Geochemistry of Mineral Deposits, Part A. Processes, Techniques, and Health Issues: Society of Economic Geologists. Reviews in Economic Geology, 6, 71-116

Reid ME (2004) Massive collapse of volcano edifices triggered by hydrothermal pressurization. Geology 32:373-376

Ritchie LT, Pritchard D (2011) Natural convection and the evolution of a reactive porous medium. J Fluid Mech 673:286-317

Robb L (2005) Introduction to ore-forming processes. Blackwell Science Ltd (384)

Rye RO (1993) The evolution of magmatic fluids in the epithermal environment: the stable isotope perspective. Economica Geologica 88:733-753

Rye RO (2005) A review of the stable-isotope geochemistry of sulphate minerals in selected igneous environments and related hydrothermal systems. Chem Geol 215:5-36

Saar MO, Manga M (2003) Seismicity induced by seasonal groundwater recharge at Mt. Hood, Oregon. Earth and Planetary Science Letters 214:605-618

Sandri L, Tonini R, Rouwet D, Constantinescu R, Mendoza-Rosas AT, Andrade D, Bernard B (2017) The need to quantify hazard related to non-magmatic unrest: from BET_EF to BET_UNREST. This volume

Shibata T, Akita F (2001) Precursory changes in well water level prior to the March, 2000 eruption of Usu volcano, Japan. Geophys Res Lett 28:1799-1802 
Sorey ML, Evans WC, Kennedy BM, Farrar CD, Hainsworth LJ, Hausback B (1998) Carbon dioxide and helium emissions from a reservoir of magmatic gas beneath Mammoth Mountain, California. J Geophy Res: Solid Earth 103:15303-15323

Sparks RSJ (2003) Forecasting volcanic eruptions. Earth Planet Sci Lett 210:1-15

Stefansson A, Gislason SR (2001) Chemical weathering of basalts, Southwest Iceland: effect of rock crystallinity and secondary minerals on chemical fluxes to the ocean. Am J Sci 301:513-556

Symonds RB, Gerlach TM, Reed MH (2001) Magmatic gas scrubbing: implications for volcano monitoring. J Volcanol Geoth Res 108:303-341

Tanguy JC (1994) The 1902-1905 eruptions of Montagne Pelee, Martinique: anatomy and retrospection. J Volcanol Geoth Res 60:87-107

Tapponnier P, Brace WF (1976) Development of stress-induced microcracks in Westerly granite. Int $\mathrm{J}$ Rock Mech Min Sci 13:103-112

Taran Y, Rouwet D, Inguaggiato S, Aiuppa A (2008) Major and trace element geochemistry of neutral and acidic thermal springs at El Chichon volcano, Mexico. J Volcanol Geoth Res 178:224-236

Tassi F, Vaselli O, Capaccioni B, Macias JL, Nencetti A, Montegrossi G, Magro G (2003) Chemical composition of fumarolic gases and spring discharges from El Chichon volcano, Mexico: Causes and implications of the changes detected over the period 1998-2000. J Volcanol Geoth Res 123:105-121

Open Access This chapter is licensed under the terms of the Creative Commons Attribution 4.0 International License (http://creativecommons.org/licenses/by/4.0/), which permits use, sharing, adaptation, distribution and reproduction in any medium or format, as long as you give appropriate credit to the original author(s) and the source, provide a link to the Creative Commons license and indicate if changes were made.The images or other third party material in this chapter are included in the
Varekamp JC (2008) The volcanic acidification of glacial Lake Caviahue, Province of Neuquen, Argentina. J Volcanol Geoth Res 178:184-196

Varekamp JC, Ouimette AP, Herman SW, Bermudez A, Delpino D (2001) Hydrothermal element fluxes from Copahue, Argentina: A "beehive" volcano in turmoil. Geology 29:1059-1062

Varekamp JC, Ouimette AP, Herman SW, Flynn KS, Bermudez A, Delpino D (2009) Naturally acid waters from Copahue volcano, Argentina. Appl Geochem 24:208-220

Weis P (2015) The dynamic interplay between saline fluid flow and rock permeability in magmatic-hydrothermal systems. Geofluids 15:350-371

Wolff-Boenisch D, Gislason SR, Oelkers EH, Putnis CV (2004) The dissolution rates of natural glasses as a function of their composition at $\mathrm{pH} 4$ and 10.6, and temperatures from 25 to $74 \mathrm{C}$. Geochim Cosmochim Acta 68:4843-4858

Wolff-Boenisch D, Gislason SR, Oelkers EH (2006) The effect of crystallinity on dissolution rates and $\mathrm{CO}_{2}$ consumption capacity of silicates. Geochim Cosmochim Acta 70:858-870

Zakharova EA, Pokrovsky OS, Dupre B, Gaillardet J, Efimova LE (2007) Chemical weathering of silicate rocks in Karelia region and Kola peninsula, NW Russia: assessing the effect of rock composition, wetlands and vegetation. Chem Geol 242:255-277 chapter's Creative Commons license, unless indicated otherwise in a credit line to the material. If material is not included in the chapter's Creative Commons license and your intended use is not permitted by statutory regulation or exceeds the permitted use, you will need to obtain permission directly from the copyright holder. 